\title{
Restrictive Factors and Countermeasures of Tribal Economic and Social Development
}

\author{
Manish Gupta \\ Department of Economics, S. K. M. University, Dumka, India
}

\begin{abstract}
Jharkhand is a tribal dominated state, and with the formation of the state in the year 2000, the age old dream of a separate state of tribals came to be true, but the very purpose with which the state was formed, i.e. the economic upliftment of the tribals still remains a dream even after two decades of its formation. The irony is that it is the richest state of India in terms of mineral resources, rightly nicknamed as the 'Ruhr of India', but its per capita income, and economic parameters reflect it as a poor state and places it among the poverty struck least developed states. It can be rightly said that 'poverty exists admist plentitude; in Jharkhand. Poverty and unemployment has pushed its innocent tribal youths towards migration to other states as labors, and some other anti-social activities. The state is not able to tap its human resource to its benefit. This grim picture opines that either right policies for tribal upliftment are not made and or those policies are not implemented at the ground level. Whatever may be the cause, the poverty struck innocent tribals are at the receiving end. This article is a legitimate attempt to identify problems existing at the grass root level in the course of economic upliftment of tribal population in the state. It also scrutinizes the constraints that act as bottleneck in erasing those problems. Lastly, this article sincerely proposes some strategies that may be benignant for the policy framers and its implementers, for the economic upliftment of tribals in Jharkhand. This article may be the 'means' to achieve the 'end; the end being tribal welfare.
\end{abstract}

Keywords: Tribal, dominated, economic upliftment, per capita income, economic parameters, plentitude, poverty, migration, implemented, strategies, constraints.

\section{Introduction}

Jharkhand state is situated in the north - eastern part of the Indian sub - continent extending from $21^{0} 58^{\prime} 10^{\prime \prime}$ to $25^{\circ} 19^{\prime}$ 15" North latitudes and $83^{\circ} 20^{\prime} 50^{\prime \prime}$ to $88^{\circ} 4^{\prime} 40^{\prime \prime}$ East longitudes. It extends to $380 \mathrm{~km}$ from North to South and $463 \mathrm{~km}$ from East to West. With an area of 79, $714 \mathrm{~km}^{2}$, occupying $2.34 \%$ of the area of India, and is home to $2.62 \%$ of the total population of India, as per the Indian Population Census Report 2011.

Jharkhand is well known as the 'Ruhr of India'. It boasts of having $40 \%$ of mineral resources and $29 \%$ coal reserves of India. It is naturally endowed with minerals like Bauxite, Chromite, Dolomite, Mica, Iron ore, Copper, Limestone, Asbestos, Uranium, Sillimanite, Gold, Graphite, Manganese, Pyrite, Silver, and Coal etc. The key industrial areas of the state are Jamshedpur, Dhanbad, Bokaro, Deoghar, Hazaribagh, Singhbhum, Ghatshila etc.

Availability of location - specific advantage makes it conducive for growth of industries like, metal extraction and mining, iron and steel, mineral processing, chemical and food processing, infrastructural industries, power generation, engineering works, manufacturing etc.

The state has rich potential to develop itself in the sectors of agro - based industries, education, healthcare, tourism, dairy, animal husbandry, forest products etc. These are some of the bright side of the state.

The dark side of the state lies in the bitter fact that about $37 \%$ of the population of Jharkhand lives below poverty line. Its literacy rate is $66.4 \%$. The per capita income in FY 2018 was Rs.63, 754 per annum, the fourth lowest position in India, the lowest ones being Bihar (Rs.38, 860), Uttar Pradesh (Rs.55, 339) and Manipur (Rs.58, 501) per annum in the FY 2018, as per the Ministry of Statistics and Programme Implementation, Govt. of India.

The condition of agricultural sector is quite deplorable, only $23 \%$ of land of Jharkhand is fit for cultivation. Out of this only $10 \%$ of cultivable land has got an access to irrigational facilities. Being a plateau region, land is rough in terrain, due to which the size of plots are quite less making them uneconomical to use modern machines in agriculture. Wells and tube - wells are hard to be made because the land is rocky and the water table is quite low. Agriculture thus, remains primitive depending upon the vagaries of monsoons.

It can be rightly attributed that, the felicity of plentitude of Jharkhand is garnered by a handful of capitalists, while the adversities of the state falls in the share of the masses, pushing them to the brink of extreme poverty. It is right that, here, 'poverty exists admist plentitude'. The most affected by this misfortune are the tribal population, who are cut - off from mainland and dwell in remote inaccessible areas, devoid of education, health care facilities and the illumination of economic growth and development.

Those people or groups, who live in natural habitat of forests and lead their own way of life, language, practices and traditions and preserve them in their societies, are called tribals. According to Indian population census 2001, the total population of tribals was $70,87,068$, which was nearly one fourth $(26.3 \%)$ of the total population of Jharkhand.

The districts with maximum population of scheduled tribes are Ranchi, West Singhbhum, Gumla and Dumka. According to Article - 342 of the Indian constitution, in 2003, there are 32 scheduled Tribes in Bihar/Jharkhand.

Out of the scheduled tribes of Jharkhand the Maximum number is of Santhals (35\%), followed by Uraons (18.14\%), 
Munda (14.56\%), Ho (9.23\%), Kherwar (3.83\%), Lohra, Kharia, Bhumij etc. being other prominent tribes.

The main occupations of scheduled tribes are hunting agriculture, animal husbandry, artisans, craft, forestry etc. . Most of them practice shifting cultivation. Agriculture for them depends upon the vagary of monsoon, and thus most of them comprise of marginal farmers, with subsistence farming. Seasonal unemployment is the most prominent problem for them and is responsible for push factors for their migration in search of employment to other adjoining states.

This article studies the ground reality, problems and constraints in the path of economic development of tribals and suggests some proactive measures and strategies for their economic upliftment. This article is a sincere effort in the direction of suggesting ways for tribal welfare, and will definitely be an important tool for the policy framers as well as policy implementers. It is high time that the dreams and aspirations of the tribal folk become a fruitful reality.

\section{Literature Review}

Inspite of the fact that there is a wide gap in the area of research literature regarding economic upliftment of tribal population in Jharkhand, some of the literature concerned with economic development of Tribals both at national and global levels are as follows:-

1) Marketing of Sabai Grass in Socio - Economic Development of Tribals in Mayurbhanj District, Orissa (India). Article by: Priti Ranjan Hathy February 2010. International Journal of Business and Management. Vol.5, No.2.

The article accords to innovative schemes and the role of Sabai grass industry for the economic development of the growers of Mayurbhanj district. It finds out the innovative marketing schemes, problems and suggests suitable measures for solving them. It further explores the involvement of existing agencies for development by various ways.

The article is localized in nature, and lacks multi dimensional approach towards tribal economic upliftment.

2) The Silenced Drums: A Review of Tribal Economic Development By. K. G. Karmkar Northern Book Centre, New Delhi., ISBN 81 - 7211 - 122 - 32002.

The book critically analyses various welfare programmes implemented and their impact at grass - root level in the state of Orissa. It uses the policy research as a tool for analyzing social, multiple aspects concerning tribal life. It identifies that the tribal economy is mainly based upon minor forest produce, cultivation of medicinal plants, art and crafts and lastly prescribes alternate policies for tribal welfare.

3) Improving Economic Development for Tribes Southeastern Oklahoma State University August 30, 2016

This article speaks positively about tribal economic growth in the U. S., It suggests ways to improve tribal citizen's quality of life, by quality education, higher standard of living and housing, better employment opportunities and stronger infrastructure.

4) Tribal Economies: Water Settlements, Agriculture and Gaming in the Western U. S. By Suhina Deol, Bonnie Colby , Journal of Contemporary Water Research \& Education

The paper examines patterns in water rights quantification, agriculture, gaming and economic characteristics across selected Native American Nations in the United States to provide a perspective across tribal nations and regions. It identifies causes and effects among different components of tribal economic development and illuminates differences among tribal nations and regions, and provides context for tribal leaders to cultivate sustainable, resilient economies and water resource management.

\section{Methodology}

Secondary data from various government reports, Govt. of India Census reports, Ministry of Rural Development, Govt. of Jharkhand, news paper reports, articles, research articles etc. have been compiled along with grassroot level experience and presence in the tribal society of Jharkhand, to study cases and problems of tribal society and its viable solutions possible with on the ground reality of the state's resources.

Problems and Constraints in the Path of Economic Upliftment of Tribals in Jharkhand:

In order to carve out the strategies of economic upliftment of the tribals of Jharkhand it is important to identify the problems and constraints involved, which are the sources of perplexity of the tribals. Some of the problems and constraints in the path of economic upliftment of tribals of Jharkhand are as follows: -

1) Formation of quality human resource: Jharkhand is gifted with a hardworking population but a large percentage of it is uneducated and poorly qualified for technical and industrial jobs. The major bottleneck lies in the fact that the state has a corrupt and dilapidated educational system. This leads to a very slow pace of transforming the potential human resources into quality labor force, which is in great demand for this progressing state. Most of the technically qualified labors working in the state are hired from neighbouring states.

2) Colonial Era Land Ownership Laws: Most of the laws related to land ownership or Tenancy laws are of colonial era with conservative ideology that prevents the sale or transfer of land ownership rights to those who want to use it for industrial or commercial purposes. Most of the unutilized tribal land which could have fetched them a handsome amount after sale due to its prime location, are leased out at very petty amounts. Development on such land becomes difficult as banks abstain from financing on projects built on leased land.

3) Backwardness of Agriculture: Backwardness of agriculture in Jharkhand is a major constraint in economic upliftment of tribals as it is the main source of occupation for them. Approximately 75 percent of tribal population is directly dependent upon agriculture and its 
allied activities for their livelihood. Backwardness of agriculture directly effects their income earning capability and makes them easy prey into the viscious circle of poverty.

\section{Backwardness of agriculture}

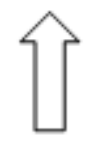

Excessive dependence on agriculture

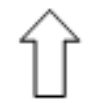

Low income earning capability

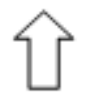

Poor quality of human resource

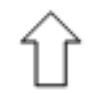

Less expenditure on health nutrition and education

4) Poorly developed industrial infrastructure: Rapid industrialization is the answer to many problems like unemployment, poverty, economic and social backwardness and their sister concerns. Jharkhand has a visible regional dualism, i. e. Southern industrialized region and the Northern and Eastern region which falls into the category of very backward regions interms of industrial progress. Tribal dominated Santhal Pargana region is one of the least industrialized region in India, with the bitter fact that the area is very rich in mineral and forest resources. Rail road and air connectivity is in its infancy stage, power cuts a regular accepted custom of the area that acts as a major constraint in industrial development.

5) Lack of Higher Technical and Educational Institutions: Jharkhand state lacks higher technical and educational institutions like the Indian Institute of Technology, Medical colleges, Engineering colleges, reputed academic institutions etc., because of which a regular migration of students is taking place, which results into the brain drain of the state. The poor tribal folk can hardly afford to send their siblings out of the state for better educational options because of which they lag behind in terms of quality education out reach. In terms of quality education infrastructure also the northern and eastern part of Jharkhand lags far behind in comparison to its southern part.

6) Lack of storage and marketing facilities: The biggest constraints in tribal economic upliftment is the lack of storage and marketing facilities. The tribals have small dwelling houses, in which they can hardly store the agricultural produce, to sell them at higher costs in the lean season. Lack of storage facilities forces them to sell their produce in the season of plentitude to the middlemen at very low prices. Lack of marketing facilities adds to their woes as they are hardly left with any other option but ot sell their produce at low prices to the middlemen. The tribals swet in the fields only to be exploited at the hands of middlemen who grab the lion's share of profit by storing and selling the agricultural produce during the lean season when the prices are soaring high.

7) Rampant corruption: Rampant corruption existing in each and every department is another hurdle in the path of economic upliftment of tribals, as it leaves a visible gap in between the targets of major poverty alleviation and welfare schemes and its outcome at the ground level. There is also wide rift in between the claims made on paper and that of reality at grassroot level, when it comes to the status of original beneficiaries and that claimed in files.

8) Vote - bank dynamics: The political masters of the state, lack the will and necessary vision to act honestly in the direction of socio - economic upliftment of the tribal population. The fruits of reservation are consumed by the elite class of tribal population, because of which the rich tribal folk are becoming richer and the poor ones are becoming poorer. The handful of influential tribals decide the fate of entire tribal population only in their favour and the innocent poor who comprises of the majority of tribal population are irrelevant in political decision making. Vote - bank dynamics, abstain the political parties from taking some strong ethically and economically correct decisions, instead they go for freebies, which give them cheap popularity. Politically correct decisions are mostly economically disastrous for the state.

\section{Strategies of Economic Upliftment of Tribals}

Some of the strategies that may be effective towards economic upliftment of Tribals are as follows: -

1) Overhauling of the entire educational infrastructure especially in the economically backward rural areas and establishment of quality technical and academic institutions in backward areas may be milestone in creating and efficient human resource. Transforming the hardworking tribal population into skilled human resource will act as the foundation stone in tribal upliftment.

2) Restoration and promotion of traditional employment opportunities like weaving, wood craft, bamboo craft, metallurgy etc. will strengthen the tribal population economically and provide them self - employment opportunities Encouraging cottage and small scale industries will also develop entrepreneurial zeal among tribals and transform them from job seekers to job givers and job creators.

3) Rapid industrialization with special focus on cottage and small scale industries will mitigate the incidence of migration of labors, as, such types of industries create more employment in comparison to large scale automated production processes. Jharkhand has a huge potential of small scale and cottage industries owing to its rich mineral availability along with the forest resources which are the raw materials for most of the small scale and cottage industries. What needs to be done is to tap those resources efficiently and adequately. The industrial department will have to be more efficient, hardworking and proactive in this regard of developing mineral processing and extraction based industries.

4) Amendment of colonial land laws which make most of the tribal land unsalable can be a very bold strategy in 
the direction of tribal land development. If their land will be saleable in nature, the tribal folk will get more revenue after selling their land, with which their standard of living will improve drastically, which otherwise fetch them a very meager amount. Then such properties will be financed easily by the commercial banks and developmental process of such land will accelerate in leaps and bounds. The rich farmer families of Punjab, Haryana and Delhi NCR are living examples of it, who got crores of rupees after selling small plots of land, near the Delhi NCR.

5) Manifestation of entrepreneurial zeal among tribal youth will transform their mindset from job hunters to job creators. The solution to tribal unemployment lies in the fact that the tribal youth will have to come to the forefront with a new and bold zeal of responsibility, self - respect and entrepreneurial acumen rather than staring at the Government for support.

6) With the presence of lofty hills, several rivers and ravines, wide variety of flora and fauna, the state has an enormous potential of expansion of service sector in the areas of hotels, restaurants, tourism, education, transportation, etc. Service sector has a huge scope of expansion thereby providing employment opportunities to the tribal youth and help them in economic upliftment.

7) Political stability and the honest vision of framing policies in favor of upliftment of Tribal of Jharkhand is the need of the hour, if, at all any or all of these policies or strategies are to be implemented on ground. Some of plans and policies may go against the vote - bank dynamics of the political masters of the Government. It is better to administer bitter medicines rather than sweeteners like freebies because a toddler can never gain the will power of walking or even running till there is a finger offered to him for help or support. But the harsh reality is that it is better said than done.

\section{Conclusion}

Inspite of more than two decades of the creation of the state of Jharkhand the life of a majority of tribal population hasn't changed much. Jharkhand still remains a state where poverty exists admist plentitude. The very purpose, (i. e. the economic upliftment of tribals), for which the state was carved out, still remains a distant dream for the poor rural tribal folk of Jharkhand. The major cause being the politically correct populist policy of offering freebies to the tribals, who are innocent enough to be contented with it.

\section{References}

[1] Priti Ranjan Hathy: 'Marketing of Sabai Grass in Socio Economic Development of Tribals in Mayurbhanj District, Orissa (India) 'Internatinal Journal of Business and Management. vol.5, No.2.

[2] K. G. Karmkar: 'The Silenced Drums: A Review of Tribal Economic Development' 2002 Northern Book Centre, New Delhi, ISBN 81 - 7211 - 122 - 3.

[3] https: //online. se. edu/articles/mba/improving economic - development - for - the - tribes. aspx.

[4] https: //doi. org/10.1111/j.1936 - 704x.2018.03269. x
[5] www.swaniti. com/wp - content/uploads/2017/11/brief Note - on - Jharkhand - Development. pdf.

[6] https: //www.phdcci. inupload $>2019 / 01>$ Rising Jharkhand - Economic - profile - PHD - Chamber.

[7] https: //ir. nbu. ac. in/bitstream/123456789/2640/15/15 chapter7. pdf. 